\title{
PEMATUHAN DAN PENYIMPANGAN PRINSIP KESANTUNAN BERBAHASA DALAM WACANA BUKU TEKS BAHASA INDONESIA
}

\author{
Nur Nisai Muslihah ${ }^{1}$, Riko Febrianto ${ }^{2}$ \\ STKIP-PGRI Lubuklinggau ${ }^{1,2}$ \\ nurnisai@yahoo.co.id ${ }^{1}$
}

Submit, 08-12-2017 Accepted,31-12-2017 Publish,31-12-2017

\begin{abstract}
ABSTRAK
Tujuan penelitian ini untuk mendeskripsikan bentuk pematuhan dan penyimpangan prinsip kesantunan berbahasa serta tingkat kesantunan berbahasa dalam wacana buku teks yang difokuskan pada buka Bahasa Indonesia SMA/MA/SMK/MAK Kelas X Kurikulum 2013 Edisi Revisi 2016 Karangan Suherli dan Kawan-kawan. Metode yang digunakan dalam penelitian ini adalah metode deskriptif kuantitatif dengan teknik baca dan catat sebagai pengumpul datanya. Analisis data menggunakan metode padan. Penentuan bentuk pematuhan dan penyimpangan prinsip-prinsip kesantunan berbahasa mengacu teori kesantunan dan prinsip kesantunan Leech. Sedangkan penentuan tingkat kesantunan dihitung berdasarkan kecenderungan bentuk pematuhan dan penyimpangan terhadap prinsip kesantunan berbahasa. Hasil penelitian menunjukkan bahwa terdapat 211 tuturan baik mematuhi maupun menyimpang terhadap prinsip kesantunan. Pematuhan berjumlah 157 tuturan, yang terdiri atas 63 maksim kebijaksanaan, 6 maksim kedermawanan, 18 maksim penghargaan, dan 70 maksim permufakatan. Penyimpangan prinsip kesantunan berbahasa memiliki proporsi yang lebih rendah yaitu 54 tuturan, yang terdiri dari 52 maksim kebijaksanaan, dan 2 maksim penghargaan. Tingkat kesantunan berbahasa dalam wacana buku teks Bahasa Indonesia SMA/MA/SMK/MAK Kelas X Kurikulum 2013 Edisi Revisi 2016 Karangan Suherli dan Kawan-kawan dikategorikan santun. Hal ini terlihat dari tingkat pematuhan memiliki persentase $74,4 \%$ yang berada pada rentang $61 \%$ - $80 \%$ dengan kategori santun, dan penyimpangan memiliki persentase $25,6 \%$ yang berada pada rentang $21 \%$ - $40 \%$ dengan kategori santun.
\end{abstract}

Kata Kunci: Pematuhan, Penyimpangan, Kesantunan Berbahasa, Wacana, Buku Teks.

\section{ABSTRACT}

The purpose of this study was to describe the form of compliance and deviation of the principle of language politeness as well as the level of language politeness in the textbooks were focused on Bahasa Indonesia textbook of SMA/MA/SMK /MAK Class X Curriculum 2013 Revised Edition 2016 by Suherli etc. The method used in this study was quantitative descriptive method by using reading and recording as data collecting technique. Data analysis was done by using matching method. The determination of the form of complience and deviation of the principles of language politeness refered to the theories of politeness and Leech's politeness principles. While the the level of politeness was calculated based on the tendency compliance and deviations on the principle of 
language politeness. The results showed that there were 211 speech either obey or deviate to the principle of politeness. The obedience amounted to 157 speech, consisting of 63 maxims of wisdom, 6 generosity maxims, 18 reward maxims, and 70 maxim of consensus. The deviation of the principle of language politeness had a lower proportion of 54 speech, consisting of 52 maxims of wisdom, and 2 maxims of appreciation. Level of discourse politics contained in textbooks Indonesian SMA/MA/SMK/MAK Class $X$ Curriculum 2013 revised edition 2016. It can be seen from the compliance rate having $74.4 \%$ percentage which is in the range of $61 \%$ - $80 \%$ with the polite category, and the deviation has the percentage of $25.6 \%$ which is in the range of $21 \%$ - $40 \%$ with the polite category.

Keywords: Compliance, Deviation, Modesty, Discourse, Textbook.

\section{PENDAHULUAN}

Bahasa merupakan sarana komunikasi dan interaksi bagi manusia dalam kehidupan masyarakat. Hal ini sejalan dengan pendapat Chaer (2010) bahwa komunikasi interaksi yang terjadi antara manusia dengan sesama anggota masyarakat dalam kehidupan sehari-hari berbentuk tuturan yang menggunakan bahasa sebagai sistem lambang bunyi. Sistem ini memiliki unsur yang terdiri atas fonem, morfem, kata, frase, klausa, kalimat, dan wacana. Wacana merupakan suatu konstruksi yang terdiri atas kalimat yang satu diikuti oleh kalimat lain yang merupakan suatu keutuhan konstruksi dan makna (Samsuri, dalam Pranowo, 2014). Hal ini mengisyaratkan bahwa wacana dapat berbentuk lisan maupun tulis (teks). Kewacanaan suatu teks dalam sebuah wacana berdampak pada pemahaman pembaca terhadap sebuah teks karena kewacaanaan berkaitan dengan interpretasi pembaca terhadap siapa, kapan, situasi semacam apa, serta apa maksud wacana tersebut.

Wacana yang utuh mencakup aspek-aspek yang padu dan menyatu, meliputi aspek kohesi, koherensi, topik wacana, aspek leksikal, aspek gramatikal, aspek fonologis dan aspek semantis (Mulyana, 2005). Terkait hal ini Samsuri (dalam Pranowo, 2014) mengemukakan bahwa ada 7 syarat kewacanaan suatu teks, yaitu: 1) kohesi, 2) koherensi, 3) intensionalitas, 4) akseptabilitas, 5) informativitas, 6) situasionalitas, dan 7) keinterwacanaan. Ketujuh syarat tersebut harus ada dalam suatu teks wacana.

Teks sebuah wacana merupakan objek kenikmatan. Hal ini sejalan dengan pernyataan Barthes dalam Sobur, 2012) bahwa "The Text is the object of pleasure". Terkait dengan hal ini Sobur mengemukakan bahwa kenikmatan dalam pembacaan 
sebuah teks adalah kesenangan kala menyusuri halaman demi halaman objek yang dibaca. Kenikmatan pembacaan ini bersifat individual karena masing-masing pembaca memiliki interpretasi yang berbeda-beda. Hal inilah yang menunjukkan adanya suatu komunikasi antara penulis dan pembaca atau penutur dan mitra tutur.

Kegiatan berkomunikasi dalam sebuah wacana, terlihat pada aspek sebuah tuturan yang meliputi pilihan kata (diksi), struktur kalimat atau tuturan, ragam bahasa yang dipakai, konteks komunikasi, pemanfaatan contoh dan ilustrasi yang sesuai dengan konteks yang menyertai peristiwa tutur. Hal inilah yang akan melahirkan suatu sikap yang disebut kesantunan berbahasa (Pranowo (2014). Selanjutnya Muslich (2006) menjelaskan bahwa kesantunan (politiness), kesopansantunan, atau etiket adalah tatacara, adat, atau kebiasaan yang berlaku dalam masyarakat.

Kesantunan merupakan aturan perilaku yang ditetapkan dan disepakati bersama oleh suatu masyarakat tertentu sehingga kesantunan sekaligus menjadi prasyarat yang disepakati oleh perilaku sosial., Secara implisit Pranowo (2012) menyatakan bahwa ketika seseorang sedang berkomunikasi, hendaknya disampaikan dengan baik dan benar juga santun dengan menggunakan kaidah kesantunan dalam setiap tindak bahasa.

Tuturan yang santun berusaha meminimalkan ungkapan yang tidak melukai hati mitra tutur (Leech dalam Pranowo, 2012). Dalam hal ini Leech mengemukakan prinsip kesantunan berbahasa yang terdiri atas 7 maksim, yaitu: a) maksim kebijaksanaan (tact maxim) ; b) maksim kedermawanan (generosity maxim); c) maksim pujian (praise maxim); d) maksim kerendahan hati; e) maksim kesetujuan (agreement maxim); f) maksim simpati (sympathy maxim); dan g) maksim pertimbangan (consideration maxim). Berdasarkan ketujuh maksim tersebut, santun tidaknya sebuah tuturan dapat dilihat dari pematuhan dan penyimpangan terhadap maksim-maksim tersebut yang selanjutnya menjadi dasar untuk menentukan skala kesantunan.

Dalam konteks bahasa tulis, istilah penutur dan mitra tutur menjadi tidak relevan

Akarena dalam bahasa tulis komunikasi disampaikan melalui tulisan. Dalam konteks ini, lebih tepat digunakan istilah penutur dan lawan tutur. Komunikasi secara tertulis dilakukan secara tidak langsung antara penutur dan mitra tutur, sehingga penutur dapat memanfaatkan media untuk menyampaikan informasi kepada mitra tutur. Tuturan yang berbentuk tulisan tersebut dapat diekspresikan melalui media cetak, salah satunya adalah buku teks. 
Buku teks adalah buku pelajaran dalam bidang studi tertentu yang merupakan buku standar, disusun oleh para pakar dalam bidang studi tertentu buat maksud-maksud dan tujuan instruksional, dilengkapi dengan sarana-sarana pengajaran yang serasi dan mudah dipahami oleh pemakainya di sekolah-sekolah dan perguruan tinggi, sehingga dapat menunjang program pengajaran (Tarigan, 2009). Oleh karena itu, penyusunan buku teks hendaknya memenuhi persyaratan kelayakan. Kelayakan sebuah buku teks dapat dilihat dari aspek isi/materi, penyajian, grafika, dan aspek kebahasaan.

Aspek kebahasaan ini menjadi sarana utama dalam penyusunan buku teks. Dengan bahasa, penulis sebagai penutur bahasa berusaha menyampaikan materi pembelajaran. Materi pembelajaran yang diperoleh melalui buku teks atau buku pelajaran menjadi sumber belajar yang memuat nilai-nilai kesantunan berbahasa baik secara eksplisit maupun implisit. Mengingat buku teks sering digunakan guru dan peserta didik sebagai referensi utama dalam pembelajaran, maka buku teks dapat menjadi role model bagi peserta didik. Buku teks atau buku pelajaran yang disediakan sekolah biasanya disalurkan oleh pemerintah. Namun, tidak menutup kemungkinan buku teks yang beredar di pasar bisa menjadi pilihan guru sebagai referensi dalam mengembangkan materi. Oleh karena itu, penyusunan buku teks perlu memperhatikan pematuhan terhadap prinsip-prinsip kesantunan berbahasa.

Kesantunan berbahasa menjadi hal yang sangat penting bagi peserta didik termasuk di SMK/MAK, karena motto dari SMK/MAK yang dicanangkan pemerintah adalah "Siap Kerja" dan "SMK Bisa!". Setelah peserta didik menyelesaikan sekolah, maka diharapkan bisa masuk dan mampu bersaing di dunia usaha dan industri karena peserta didik terlebih dahulu mengikuti magang sebagai pengenalan dengan dunia kerja. Pembelajaran bahasa Indonesia mempunyai andil yang cukup besar dalam membentuk sikap siswa, terutama dalam proses berkomunikasi untuk menghasilkan bahasa yang santun. Oleh karena itu, aspek kesantunan berbahasa perlu diperhatikan, baik dalam pembelajaran, materi pembelajaran, dan dalam pengembangan alat evaluasi.

Materi pembelajaran untuk jenjang pendidikan tingkat SMK/MAK dalam buku teks yang direvisi pada yahun 2016 ditujukan hanya untuk kelas X saja. Dalam hal ini, buku teks Bahasa Indonesia juga mendapat perhatian. Harapannya, buku teks tersebut dapat digunakan guru maupun peserta didik sebagai referensi ataupun sumber belajar. 
Pemilihan buku teks untuk kelas $\mathrm{X}$ berjudul "Bahasa Indonesia SMA/MA/SMK/MAK Kelas X Kurikulum 2013 Edisi Revisi 2016" yang diterbitkan Kementerian Pendidikan dan Kebudayaan sebagai objek penelitian ini didasarkan pada prinsip bahwa lulusan SMK/MAK dipersiapkan agar mampu bersaing di dunia usaha dan dunia industri karena salah satu bekal yang harus dimiliki dapat diperoleh peserta didik melalui pembelajaran bahasa Indonesia. Oleh karena itu, peneliti tertarik untuk mengadakan penelitian dengan judul "Pematuhan dan Penyimpangan terhadap Prinsip Kesantunan Berbahasa dalam Wacana Buku Teks Bahasa Indonesia”.

\section{METODE PENELITIAN}

Penelitian ini menggunakan metode deskriptif dengan pendekatan kuantitatif untuk menggambarkan dan menginterpretasi objek sesuai dengan apa adanya berdasarkan kondisi objek yang ada (Sukmadinata, 2010). Pengambilan sumber data dilakukan dengan triangulasi (gabungan), analisis data bersifat induktif, dan hasil penelitian ini lebih menekankan makna dari pada generalisasi" untuk mengungkapkan bentuk dan tingkat pematuhan serta penyimpangan terhadap prinsip kesantunan berbahasa dalam wacana buku teks yang diteliti.

Data yang dikumpulkan merupakan dekripsi tuturan berupa kalimat-kalimat yang terdapat dalam wacana pada buku teks. Selanjutnya data dianalisis yang dianalisis berdasarkan konteksnya dengan menerapkan prinsip-prisip kesantunan yang dikemukakan Leech (dalam Rahardi, 2005) yang terdiri dari maksim kebijaksanaan, maksim kedermawanan, maksim penghargaan, maksim kesederhanaan, maksim permufakatan, dan maksim kesimpatian.

Instrumen utama dalam penelitian ini adalah peneliti sendiri (human instrument), sebagai orang yang berkecimpung dalam dunia akademisi dan bekal pengetahuan dalam bidang lingusitik (pragmatik) sekaligus sebagai penganalisis data. Peneliti menggunakan instrumen prinsip kesantunan berbahasa untuk mengklasifikasikan tuturan yang terindikasi mematuhi maupun menyimpang dari prinsip-prinsip kesantunan berbahasa yang dikemukakan Leech. Pengklasifikasian tersebut didasarkan pada indikator-indikator yang disusun Rahardi (2005), Zamzani, dkk. (2011), dan Pranowo (2012) yang selanjutnya disesuaikan dengan maksim-maksim yang mendasarinya. Untuk lebih jelasnya dapat dilihat pada tabel 1 di bawah ini. 
Tabel 1

Indikator Pematuhan dan Penyimpangan Prinsip Kesantunan Berbahasa

\begin{tabular}{|c|c|c|c|}
\hline \multirow{2}{*}{ No. } & \multirow{2}{*}{ Maksim } & \multicolumn{2}{|c|}{ Indikator } \\
\hline & & Pematuhan & Penyimpangan \\
\hline 1. & Kebijaksanaan & 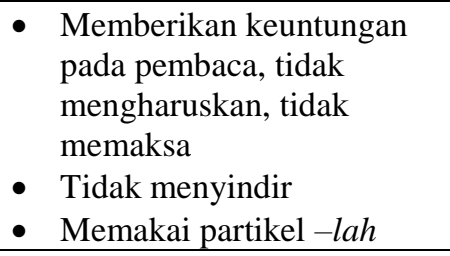 & $\begin{array}{l}\text { - Memberatkan pembaca atau } \\
\text { memaksa, mengharuskan sesuatu } \\
\text { yang tidak harus } \\
\text { - Menyindir } \\
\text { - Tidak memakai partikel -lah }\end{array}$ \\
\hline 2. & Kedermawanan & $\begin{array}{l}\text { - Tidak menguntungkan } \\
\text { penulis. }\end{array}$ & - Menguntungkan penulis \\
\hline 3. & Pujian & 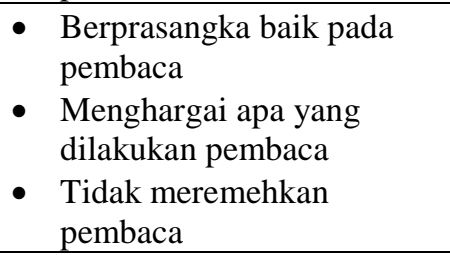 & $\begin{array}{l}\text { - Berprasangka negatif pada } \\
\text { pembaca } \\
\text { - Tidak menghargai apa yang } \\
\text { dilakukan pembaca } \\
\text { - Memerintah dengan meremehkan }\end{array}$ \\
\hline 4. & Kerendahan hati & $\begin{array}{ll}\text { - } & \text { Penulis tidak } \\
\text { menyombongkan diri } \\
\text { - } \\
\text { Tidak mengandung } \\
\text { arogansi } \\
\end{array}$ & $\begin{array}{l}\text { - Penulis menyombongkan diri } \\
\text { - Mengandung arogansi }\end{array}$ \\
\hline 5. & Permufakatan & $\begin{array}{ll}\text { - } & \text { Memberikan pilihan } \\
\text { kepada pembaca } \\
\text { - } \\
\text { Mengofirmasikan kegiatan } \\
\text { yang akan dilakukan } \\
\text { - Perintah tidak terasa } \\
\text { langsung } \\
\end{array}$ & $\begin{array}{l}\text { - Tidak memberikan pilihan kepada } \\
\text { pembaca } \\
\text { - Tidak mengonfirmasikan kegiatan } \\
\text { yang akan dilakukan } \\
\text { - Perintah langsung }\end{array}$ \\
\hline 6. & Kesimpatian & $\begin{array}{l}\text { - Memberikan simpati } \\
\text { kepada pembaca }\end{array}$ & $\begin{array}{l}\text { - Tidak memberikan simpati kepada } \\
\text { pembaca }\end{array}$ \\
\hline
\end{tabular}

Diolah dari sumber: Rahardi (2005),Zamzani, dkk. (2011), Pranowo (2012).

Selanjutnya untuk menentukan tingkat kesantunan berbahasa digunakan rumus persentase pematuhan dan penyimpangan terhadap prinsip kesantunan berbahasa sebagaimana dikemukakan Chamalah (2012) sebagai berikut: $K s=\frac{n}{\Sigma} \times 100 \%$

Keterangan: $\quad \mathrm{Ks}=$ Kesantunan

$$
\begin{aligned}
& \mathrm{N}=\text { Jumlah data pematuhan/penyimpangan } \\
& \sum \text { = Jumlah seluruh data }
\end{aligned}
$$

Kemudian dikonsultasikan dengan tabel 2 persentase pematuhan prinsip kesantunan berikut ini. 
Tabel 2

Persentase Pematuhan Prinsip Kesantunan

\begin{tabular}{cc}
\hline Persentase & Kategori \\
\hline $81 \%-100 \%$ & sangat santun \\
\hline $61 \%-80 \%$ & Santun \\
\hline $41 \%-60 \%$ & cukup santun \\
\hline $21 \%-40 \%$ & kurang santun \\
\hline $0-20 \%$ & tidak santun \\
\hline
\end{tabular}

Selanjutnya penyimpangan terhadap prinsip kesantunan berbahasa dikorelasikan dengan tabel 3 berikut.

Tabel 3

Persentase Penyimpangan Prinsip Kesantunan

\begin{tabular}{cc}
\hline Persentase & Kategori \\
\hline $0-20 \%$ & sangat santun \\
\hline $21 \%-40 \%$ & Santun \\
\hline $41 \%-60 \%$ & cukup santun \\
\hline $61 \%-80 \%$ & kurang santun \\
\hline $81 \%-100 \%$ & tidak santun \\
\hline
\end{tabular}

Perhitungan di atas dibuat berdasarkan pertimbangan bahwa semakin banyak tuturan yang melanggar maksim kesantunan, maka semakin tidak santun bahasa yang digunakan. Pembagian skala di atas dibuat karena dalam kesantunan predikat tersebut yang digunakan. Brown dan Rodgers (dalam Sosiowati, 2013) mengatakan bahwa pembagian skala tidak diharuskan harus tiga, empat, lima, enam atau tujuh. Semuanya diserahkan kepada peneliti berdasarkan pertimbangan seberapa luas sebaran poin dalam skala dan seberapa banyak perbedaan dari satu predikat ke predikat berikutnya. Data yang dianalisis dapat berdasarkan frekuensi atau persentase.

\section{HASIL PENELITIAN}

Hasil penelitian terhadap 61 wacana dalam Buku Teks Bahasa Indonesia SMA/MA/SMK/MAK Kelas X Kurikulum 2013 Edisi Revisi 2016 Karangan Suherli dan kawan-kawan, ditemukan 211 tuturan dengan 157 tuturan mematuhi dan 54 tuturan menyimpang terhadap prinsip-prinsip kesantunan berbahasa. Secara garis besar hasil penelitian ini dapat dilihat pada tabel 4 di bawah ini. 
Tabel 4

Bentuk Pematuhan dan Penyimpangan terhadap Prinsip Kesantunan Berbahasa dalam Wacana Buku Teks Bahasa Indonesia

\begin{tabular}{ccccc}
\hline \hline No & Pematuhan & $\begin{array}{c}\text { Jumlah } \\
\text { Tuturan }\end{array}$ & Penyimpangan & $\begin{array}{c}\text { Jumlah } \\
\text { Tuturan }\end{array}$ \\
\hline 1, & Maksim Kebijaksanaan & 63 tuturan & Maksim Kebijaksanaan & 52 tuturan \\
\hline 2, & Maksim Kedermawanan & 6 tuturan & Maksim Kedermawanan & 0 tuturan \\
\hline 3, & Maksim Penghargaan & 18 tuturan & Maksim Penghargaan & 2 tuturan \\
\hline 4, Maksim Permufakatan & 70 tuturan & Maksim Permufakatan & 0 tuturan \\
\hline 5, Maksim Kerendahan Hati & 0 tuturan & Maksim Kerendahan Hati & 0 tuturan \\
\hline 6, & Maksim Kesimpatian & 0 tuturan & Maksim Kesimpatian & 0 tuturan \\
\hline JUMLAH & 157 tuturan & & 54 tuturan \\
\hline
\end{tabular}

Berdasarkan tabel 4 di atas terdapat 157 tuturan yang mematuhahi prinsipprinsip kesantunan berbahasa yang terdiri atas 63 pematuhan maksim kebijaksanaan, 6 pematuhan maksim kedermawanan, 18 pematuhan maksim penghargaan, dan 70 pematuhan maksim permufakatan. Namun tidak ditemukan adanya pematuhan terhadap maksim kerendahan hati dan maksim kesimpatian. Sedangkan bentuk penyimpangannya terdiri atas 54 tuturan berupa 52 maksim kebijaksanaan, 0 maksim kedermawanan, dan 2 maksim penghargaan, 0 maksim permufakatan, 0 maksim kerendahan hati, dan 0 maksim kerendahan hati.

\section{PEMBAHASAN}

Pembahasan dalam penelitian ini didasarkan pada indikator pematuhan dan penyimpangan terhadap prinsip kesantunan berbahasa dalam wacana buku teks Bahasa Indonesia SMA/MA/SMK/MAK Kelas X Kurikulum 2013 Edisi Revisi 2016 Karangan Suherli dan kawan-kawan. Tuturan-tuturan yang ditemukan, dikaji berdasarkan prinsipprinsip kesantunan Leech, Indikator kesantunan. Sedangkan tingkat kesantunan berbahasa dalam penelitian ini didasarkan pada kecenderungan kesantunan tuturan dalam wacana buku teks tersebut. Berikut ini bentuk-bentuk pematuhan dan penyimpangan terhadap prinsip kesantunan berbahasa dalam wacana buku Teks Bahasa 
Indonesia SMA/MA/SMK/MAK Kelas X Kurikulum 2013 Edisi Revisi 2016 Karangan Suherli dan kawan-kawan.

\section{Pematuhan Prinsip-Prinsip Kesantunan Berbahasa}

\section{Maksim Kebijaksanaan}

Maksim kebijaksanaan mengatur sebuah tuturan agar tidak memberatkan mitra tutur dan setiap peserta pertuturan hendaknya berpegang pada prinsip untuk meminimalkan kerugian orang lain. Leech (2015) menjelaskan bahwa prinsip utama maksim kebijaksanaan adalah dengan meminimalkan kerugian orang lain sekecil mungkin dan buatlah keuntungan orang lain sebesar mungkin. Pematuhan maksim kebijaksanaan dalam ragam bahasa tulis dapat dilihat dari adanya sikap yang tidak memberatkan pembaca, menggunakan penghalus kalimat, tuturan yang bersifat impositif dan komisif, serta pemilihan kata yang relatif bernilai positif.

Indikator pematuhan terhadap maksim kebijaksanaan adalah penulis memberikan keuntungan kepada pembaca, tidak mengharuskan, tidak memaksa, tidak menyindir, dan menggunakan partikel -lah. Terdapat 63 tuturan yang mematuhi maksim kebijaksanaan.

Secara rinci 63 tuturan tersebut tersebar dalam beberapa 8 bab, yakni dalam bab I ada 7 (tujuh) wacana kegiatan yang berjudul Mengidentifikasi Isi Teks Laporan Hasil Observasi; Menyusun Ringkasan Isi Teks Laporan Hasil Observasi; Membenahi Kesalahan Isi laporan Hasil Observasi; Membenahi Kesalahan Bahasa Teks Laporan; Melengkapi Gagasan Pokok dengan Gagasan Penjelas; Menyusun Teks Laporan Hasil Observasi Menyusun Teks Laporan Hasil Observasi; dan wacana kegiatan yang berjudul Melaporkan Kegiatan Membaca.

Pada Bab II, terdapat 4 wacana kegiatan yang mematuhi maksim kebijaksanaan. Keempat wacana kegiatan tersebut berjudul Mengidentifikasi Tesis, Argumen, dan Rekomendasi dalam Teks Eksposisi; Membedakan Fakta dan Opini; Menentukan Gagasan Pokok dan Gagasan Penjelas dalamTeks Eksposisi; dan Menyusun teks eksposisi.

Selanjutnya terdapat 6 wacana kegiatan yang mematuhi maksim kebijaksanaan pada Bab III. Keenam wacana yang dimaksud berjudul Mendata Pokok-pokok Isi Anekdot; Mengidentifikasi Struktur Anekdot; Mengenal Berbagai Pola Penyajian Teks 
Anekdot; Menganalisis Struktur dan Kebahasaan Teks Anekdot; dan Mempresentasikan Anekdot.

Pada Bab IV terdapat 2 wacana kegiatan yang berisi maksim kebijaksanaan yaitu wacana yang berjudul Mengidentifikasi Isi Pokok Cerita Hikayat dengan Bahasa Sendiri; dan Mengidentifikasi Karakteristik Bahasa Hikayat. Empat 4 wacana kegiatan yang mengandung maksim kebijaksanaan juga terdapat pada $\mathrm{Bab} \mathrm{V}$ yang berjudul Merumuskan Ciri Negosiasi; Menggunakan Alasan yang Tepat untuk Melakukan Pengajuan dan Penawaran dalam Negosiasi; Menggunakan Alasan yang Tepat untuk Melakukan Pengajuan dan Penawaran dalam Negosiasi; Menyusun Teks Negosiasi Tulis dalam Bentuk Narasi.

Tuturan yang berisi maksim kebijaksanaan ini juga ditemukan pada lima 5 wacana kegiatan pada bab VI, yaitu pada wacana kegiatan yang berjudul Merumuskan Esensi Debat; Mengidentifikasi Unsur-unsur Debat; Merumuskan Tata Cara Debat; Menyusun Mosi; Melaksanakan Debat sesuai dengan Peran yang telah Ditetapkan. Pada bab VII ditemukan 1 wacana yang berisi maksim kebijaksanaan yang berjudul Mengidentifikasi Ciri Teks Negosiasi Berdasarkan Isinya, dan pada Bab VIII terdapat 3 wacana kegiatan yang berjudul Menentukan Suasana dalam Puisi; Menemukan Makna Puisi; dan Membacakan puisi.

Di antara contoh tuturan yang berisi pematuhan maksim kebijaksanaan ini adalah dalam wacana kegiatan yang berjudul "Mengidentifikasi Isi Teks Laporan Hasil Observasi dengan judul "Wayang" hal 9 dalam kalimat "Marilah Berlatih Mendengarkan Laporan Hasil Observasi yang Dibacakan!” (Kode data: 01/2/a). Tuturan yang berbentuk imposif dan bermakna imperatif ini mengamanatkan kepada siswa untuk berlatih mendengarkan pembacaan teks laporan hasil observasi. Penanda kesantunan "mari" sebagai penentu kesantunan tuturan bermakna imperatif ajakan, lebih santun daripada tuturan yang sama tetapi tidak menggunakan penanda kesantunan tersebut. Kadar kesantunan tuturan di atas bertambah setelah penulis memaksimalkannya dengan penggunaan partikel -lah pada kata "mari" sehingga tuturan tersebut terasa lebih halus. Tuturan tersebut juga tidak membebani atau mengharuskan siswa untuk mendengarkan pembacaan laporan hasil observasi dengan menggunakan penekanan cermat, saksama atau dengan kata suruh lainnya. 


\section{Maksim Kedermawanan}

Maksim kedermawanan menghendaki penutur berpegang pada prinsip untuk selalu mengurangi keuntungan diri sendiri. Leech (2015) menjelaskan bahwa prinsip maksim kedermawanan yaitu buatlah keuntungan diri sendiri sekecil mungkin dan buatlah kerugian diri sendiri sebesar mungkin. Pematuhan maksim kedermawanan dalam ragam bahasa tulis dapat dilihat dari adanya sikap yang tidak menguntungkan penulis.

Indikator kesantunan maksim kedermawanan ini adalah bahwa penulis tidak menguntungkan diri sendiri. Kelima wacana yang berisi maksim kedermawanan ini terdapat 6 tuturan yang tersebar dalam dalam 4 bab, yaitu dalam bab I pada wacana kegiatan yang berjudul Melaporkan Kegiatan Membaca; pada bab V terdapat dalam wacana kegiatan yang berjudul Menggunakan Alasan yang Tepat untuk Melakukan Pengajuan dan Penawaran dalam negosiasi. Selanjutnya bab VI Merumuskan Esensi Debat, dan Mengidentifikasi Ragam Bahasa Debat. Dan pada bab VIII maksim ini terdapat dalam wacana kegiatan yang berjudul Menemukan Makna Puisi.

Salah satu contoh maksim kedermawanan dapat dilihat pada wacana yang berjudul "Melaporkan Kegiatan Membaca Buku" hal 49 dalam kalimat "Untuk membantumu melaporkan kegiatan membaca, berikut ini contoh format yang dapat kaти buat" (Kode data: 68/b). Kalimat ini merupakan kegiatan akhir dalam kegiatan membaca buku nonfiksi selama seminggu yang telah dilakukan siswa. Dalam kalimat ini tersirat skala kerugian dan keuntungan (cost-benefit scale), semakin tuturan tersebut merugikan diri penutur, akan semakin dianggap santun. Selanjutnya tuturan tersebut berupa kalimat deklaratif yang tidak hanya sekedar memberikan informasi kepada pembaca terkait contoh format penulisan kegiatan membaca, tetapi penulis berusaha mengurangi keuntungannya dengan tujuan agar pembaca dapat terbantu dalam menentukan format penulisan laporan kegiatan membaca.

\section{Maksim Penghargaan}

Prinsip dasar maksim penghargaan adalah kecamlah orang sedikit mungkin dan pujilah orang lain sebanyak mungkin (Leech, 2015). Dalam menghasilkan ujaran, seseorang harus mempertimbangkan perasaan lawan tuturnya. Jangan sampai mengatakan hal-hal yang tidak menyenangkan bagi orang lain. Chaer (2010) 
menyatakan bahwa maksim penghargaan (kemurahan hati) menuntut setiap penutur memaksimalkan rasa hormat kepada orang lain dan meminimalkan rasa tidak hormat kepada orang lain.

Indikator pematuhan terhadap maksim penghargaan dalam ragam bahasa tulis dapat dilihat dari adanya prasangka baik terhadap pembaca, tuturan bersifat ekspresif, menghargai apa yang dilakukan pembaca, dan tidak meremehkan kemampuan pembaca. Terdapat 18 tuturan yang berisi maksim penghargaan ini tersebar dalam 7 bab yaitu pada bab I terdapat 3 wacana yang berjudul Melengkapi Isi Teks Laporan Hasil Observasi; Melengkapi Gagasan Pokok dengan Gagasan Penjelas; dan Menyusun Teks Laporan Hasil Observasi. Pada bab III terdapat 3 wacana kegiatan yang berjudul Membandingkan Anekdot dengan Humor; Menganalisis Kritik yang Disampaikan Anekdot; Menyimpulkan Makna Tersirat dalam Anekdot. Selanjutnya pada bab IV terdapat 3 wacana kegiatan yang berjudul Menjelaskan Kesesuaian Nilai-nilai dalam Hikayat dengan Kehidupan Saat ini dalam Teks Eksposisi; Membandingkan Nilai dalam Teks Hikayat dan Nilai Cerpen; Membandingkan Alur Cerita dalam Hikayat dan Cerpen. Pada bab V terdapat 4 wacana kegiatan yang berisi maksim penghargaan, yaitu wacana yang berjudul Menjelaskan Cara Menyampaikan Pengajuan dan Penawaran; Menggunakan Alasan yang Tepat untuk Melakukan Pengajuan dan Penawaran dalam Negosiasi; Menggunakan Kalimat Persuasif; Menyusun Teks Negosiasi Tulis dalam Bentuk Narasi. Pada bab V terdapat 3 wacana kegiatan yang berisi maksim penghargaan yaitu pada wacana yang berjudul Merumuskan Tata Cara Debat; Merumuskan Mosi Berdasarkan Isu atau Permasalahan yang sedang Berkembang; dan Melaksanakan Debat sesuai dengan Peran yang Telah Ditetapkan. Pada bab VII ada 1 wacana berjudul Menceritakan Kembali Teks Biografi dengan Pola, dan pada bab VIII ditemukan 1 wacana kegiatan yang berjudul Menemukan Makna Puisi.

Berikut adalah salah satu bentuk maksim penghargaan yang terdapat dalam wacana yang berjudul "Melengkapi Isi Teks Laporan Hasil Observasi”hal 23 dalam kalimat "Tanpa melihat kembali teks lengkapnya di atas, kamu pasti dapat menemukan bahwa teks laporan hasil observasi di atas tidak dilengkapi dengan (a) pengklasifikasian/pengelompokan objek yang diobservasi dan (b) deskripsi manfaat" (Kode data: 03/2/c). Kalimat deklaratif ini bertujuan agar siswa melengkapi isi teks laporan hasil observasi. Kalimat ini dikatakan mematuhi maksim penghargaan atau 
pujian karena sebelum tuturan ini disampaikan, penulis telah menguraikan contoh teks laporan hasil observasi berjudul "Ada Apa di D'topeng Museum Angkut”.

Pematuhan terhadap maksim penghargaan pada tuturan di atas terlihat dari kalimat yang diutarakan dengan tuturan ekspresif, karena lazimnya maksim penghargaan diutarakan dengan tuturan ekspresif yang dimaksimalkan untuk memberikan pujian. Hal ini terlihat dari usaha penulis yang berprasangka baik terhadap pembacapada kalimat (a) terlihat dari tuturan "kamu pasti dapat menemukan bahwa teks laporan hasil observasi di atas tidak dilengkapi dengan (a) pengklasifikasian/pengelompokan objek yang diobservasi dan (b) deskripsi manfaat", tuturan tersebut mengindikasikan usaha penulis dalam memaksimalkan prasangka baiknya dengan memposisikan siswa sebagai seseorang yang dapat menemukan beberapa unsure laporan hasil observasi, seperti pengklasifikasian objek dan deskripsi manfaat yang tidak terdapat dalam contoh teks laporan hasil observasi. Prasangka baik inilah yang menjadikan kalimat di atas mematuhi maksim penghargaan,

\section{Maksim Permufakatan}

Maksim permufakatan atau kesepakatan menghendaki para penutur berpegang pada prinsip untuk selalu meningkatkan persesuaian antara diri sendiri dengan orang lain. Maksim ini sebagai maksim kecocokan yang menggariskan setiap penutur dan lawan tutur memaksimalkan kecocokan di antara mereka, dan meminimalkan ketidakcocokan di antara mereka.

Indikator pematuhan maksim permufakatan dalam ragam bahasa tulis ditandai dengan sikap penulis yang memberikan pilihan kepada pembaca, mengonfirmasikan kegiatan yang hendak dilakukan pembaca, tuturan bersifat asertif, dan perintah tidak terasa langsung, misal tuturan tidak terlalu pendek.

Tuturan yang berisi maksim permufakatan ini berjumlah 70 yang tersebar dalam 7 bab dan 33 judul wacana. Terdapat 8 wacana kegiatan yang terdapat dalam bab I dengan judul Mengidentifikasi Isi Teks Laporan Hasil Observasi; Menyusun Ringkasan Isi Teks Laporan Hasil Observasi; Melengkapi Isi Teks Laporan Hasil Observasi; Membenahi Kesalahan Isi Laporan Hasil Observasi; Membenahi Kesalahan Bahasa Teks Laporan; Melengkapi Gagasan Pokok dengan Gagasan Penjelas; Melengkapi Gagasan Pokok dengan Gagasan Penjelas; Menyusun Teks Laporan Hasil Observasi; 
Melaporkan Kegiatan Membaca Pada bab II terdapat 5 wacana dengan judul Mengidentifikasi Tesis, Argumen, dan Rekomendasi dalam Teks Eksposisi; Membedakan Fakta dan Opini; Menyampaikan Kembali Gagasan dalam Teks Eksposisi dengan Bahasa yang Berbeda; Menentukan Gagasan Pokok dan Gagasan Penjelas dalam Teks Eksposisi; Menyusun Teks Eksposisi; Pada bab III terdapat 3 wacana dengan judul Mendata Pokok-pokok Isi Anekdot; Mengidentifikasi Penyebab Kelucuan Anekdot; Membandingkan Anekdot dengan Humor; dan Mempresentasikan Anekdot. Sementara itu pada bab IV terdapat 3 wacana kegiatan yang berjudul Mengidentifikasi Isi Pokok Cerita Hikayat dengan Bahasa Sendiri; Menjelaskan Kesesuaian Nilai-nilai dalam Hikayat dengan Kehidupan Saat ini dalam Teks Eksposisi; dan Laporan Membaca Buku;

Selanjutnya pada bab V terdapat 3 wacana kegiatan dengan judul Merumuskan Ciri Negosiasi; Menjelaskan Pola-pola Penyajian Teks Negosiasi; Menyusun Teks Negosiasi Tulis dalam Bentuk Narasi. Pada bab VI terdapat 5 wacana kegiatan yang berjudul Merumuskan Esensi Debat; Merumuskan Tata Cara Debat; Menyusun Mosi; Menyusun Pendapat untuk Mendukung atau Menolak Mosi; Melaksanakan Debat sesuai dengan Peran yang telah Ditetapkan. Dan pada bab VII terdapat 4 wacana kegiatan yang berjudul Mengidentifikasi Ciri Teks Biografi Berdasarkan Isinya; Menjelaskan Cara Meneladani Karakter Unggul Tokoh dengan Menggunakan Teks Eksposisi; Menemukan Pola Penyajian Karakter Unggul Tokoh; Menceritakan Kembali Isi Teks Biografi dengan Pola Penyajian yang Berbeda.

Berikut ini adalah salah satu contoh pematuhan maksim permufakatan dalam wacana yang berjudul "Mengidentifikasi Isi Teks Laporan Hasil Observasi” hal 9 dalam kalimat "Kamu diharapkan dapat mendengarkan teks berikut ini dan memahami isi teks tersebut dengan baik" (Kode data: 01/1/e). Kalimat deklaratif ini mengamanatkan kepada siswa agar mendengarkan teks laporan observasi yang dibacakan temannya. Kalimat ini mematuhi maksim permufakatan yang berisi sebagai pengantar kegiatan mengidentifikasi isi teks laporan hasil observasi. Pematuhan terhadap maksim permufakatan terlihat dari kalimat yang diutarakan dengan tuturan asertif. Lazimnya maksim permufakatan diutarakan dengan tuturan asertif yang kolaboratif dan tidak mengacuhkan tujuan sosial. Karakteristik maksim permufakatan dalam tuturan ini penulis menggunakan penanda kesantunan "harap" untuk memperhalus dan pemarkah 
tuturan bermakna imperatif harapan. Penanda kesantunan "harap" memiliki makna imbauan. Hal ini mencerminkan usaha penulis membina persesuaiannya terhadap siswa, agar siswa selaku pembaca dapat memahami isi teks tersebut dengan baik.

Di sisi lain, tidak ditemukan adanya pematuhan terhadap maksim kerendahan hati dan maksim kesimpatian dalam wacana buku teks bahasa Indonesia AMA/MA/SMK/MAK Kelas X Karangan Suheri dan kawan-kawan.

Penyimpangan terhadap Prinsip-Prinsip Kesantunan Berbahasa dalam Buku TeksBahasa Indonesia SMA/MA/SMK/MAK Kelas X Karangan Suherli danKawanKawan

\section{Maksim Kebijaksanaan}

Maksim kebijaksaan mengatur sebuah tuturan agar tidak memberatkan mitra tutur dan terasa lebih halus. Pada tindakan menghasilkan tuturan, seseorang harus bersikap arif, tidak mengeluarkan perasaan iri dan sebagainya. Penyimpangan terhadap maksim kebijaksanaan ditandai dengan pemilihan kosakata yang cenderung bernilai negatif, kasar, serta panjang-pendeknya kalimat. Dalam ragam tulis, hai ini dilihat dari adanya sikap memberatkan pembaca, tidak menggunakan penghalus kalimat, serta pemilihan kata yang relatif bernilai negatif.

Terdapat 8 judul wacana kegiatan pada bab I dengan judul Mengidentifikasi Isi Teks Laporan Hasil Observasi; Melengkapi Isi Teks Laporan Hasil Observasi; Membenahi Kesalahan Isi Laporan Hasil Observasi; Menganalisis Kebahasaan Teks Laporan Hasil Observasi; Membenahi Kesalahan Bahasa Teks Laporan; Melengkapi Gagasan Pokok dengan Gagasan Penjelas; dan Menyusun Teks Laporan Hasil Observasi; Melaporkan Kegiatan Membaca.

Pada bab II terdapat 3 wacana kegiatan yang menyimpang dari maksim kebujaksanaan yaitu dalam wacana kegiatan yang berjudul Menyampaikan Kembali Gagasan dalam Teks Eksposisi dengan Bahasa yang Berbeda; Menentukan Gagasan Pokok dan Gagasan Penjelas dalam Teks Eksposisi; dan Menyusun Teks Eksposisi. Selanjutnya pada bab III terdapat 3 wacana kegiatan dengan judul Mendata Pokokpokok Isi Anekdot; Mengenal Berbagai Pola Penyajian Teks Anekdot; dan Mempresentasikan Anekdot.

Sementara itu, pada bab IV terdapat 6 wacana kegiatan yang menyimpang dari maksim kebijaksanaan yang berjudul Mengidentifikasi nilai-nilai dalam hikayat; 
Mengidentifikasi nilai-nilai dalam hikayat yang masih sesuai dengan kehidupan saat ini; Menjelaskan kesesuaian nilai-nilai dalam hikayat dengan kehidupan saat ini dalam teks eksposisi; Mengidentifikasi karakteristik bahasa hikayat; Membandingkan alur cerita dalam hikayat dan cerpen; dan Laporan membaca buku. Pada bab V terdapat 4 wacana kegiatan yang berjudul Menjelaskan Cara Menyampaikan Pengajuan dan Penawaran; Menjelaskan Pola-pola Penyajian Teks Negosiasi; Menentukan Bagian Teks Anekdot; dan Mengidentifikasi Kalimat Persuasif dalam Teks Negosiasi.

Pada bab VI terdapat 4 judul wacana kegiatan yang berisi tuturan yang menyimpang dari maksim kebijaksanaan yaitu berjudul Merumuskan Esensi Debat; Merumuskan Mosi Berdasarkan Isu atau Permasalahan yang sedang Berkembang; Menyusun Pendapat Disertai Argumen Baik untuk Mendukung maupun Menolak Mosi; dan Mengidentifikasi Ragam Bahasa Debat. Pada bab VII terdapat 5 judul wacana kegiatan yaitu berjudul Mengidentifikasi Ciri Teks Biografi Berdasarkan Isinya; Menjelaskan Cara Meneladani Karakter Unggul Tokoh dengan Menggunakan Teks Eksposisi; Mendata Pokok-pokok Informasi dalam Teks Biografi Mendata Pokok-pokok Informasi dalam Teks Biografi; Menemukan Pola Penyajian Karakter Unggul Tokoh; dan Menceritakan Kembali Teks Biografi dengan Bahasa yang Berbeda.

Selanjutnya pada bab VIII terdapat 4 wacana kegiatan yang juga menyimpang terhadap maksim kebijaksananaan, yaitu dalam wacana yang berjudul Menganalisis diksi dalam puisi; Mengidentifikasi kata konkret dalam puisi; Menjelaskan rima/ritme dalam puisi; dan Menulis puisi berdasarkan berita yang dibaca atau didengar.

Salah satu contoh penyimpangan maksim kebijaksaan dapat dilihat dalam wacana yang berjudul "Mengidentifikasi Isi Teks Laporan Hasil Observasi" hal 9 pada kalimat "Dengarlah guru atau temanmu yang membacakan teks tersebut dengan saksama!" (Kode data: 01/4/aa). Tuturan berupa kalimat imperatif yang mengamanatkan siswa agar mendengarkan teks laporan observasi dengan saksama.

Kalimat tersebut atas menyimpang dari maksim kebijaksanaan karena sebelum kehadiran tuturan tersebut, penulis telah mengajak siswa bersama-sama untuk mendengarkan laporan hasil observasi yang dibacakan oleh guru atau temannya. Penyimpangan pada kalimat tersebut disebabkan oleh tuturan yang terkesan memberatkan pembaca. Meskipun menggunakan partikel -lah yang berfungsi untuk menghaluskan tuturan, namun kalimat tersebut menggunakan penekanan "dengan 
saksama" yang justru memberikan penekanan lebih kepada pembaca. Penggunaan "dengan saksama" pada tuturan tersebut bukan merupakan suatu anggapan terhadap apa yang dilakukan siswa, tetapi merupakan penekanan dan penyangatan (saksama memiliki intensitas yang lebih tinggi). Dalam skala keuntungan-kerugian, suatu kalimat akan semakin tidak santun jika semakin memberatkan mitra tutur. Pemanfaatan tuturan "dengan saksama" pada kalimat (5) sebenarnya bisa dihilangkan karena siswa sudah mengetahui bahwa kompetensi tersebut memang akan mereka pelajari dan berusaha akan mereka kuasai.

\section{Maksim Penghargaan}

Maksim penghargaan atau pujian menghendaki setiap tuturan memberikan sebanyak-banyaknya rasa hormat pada orang lain. Penyimpangan maksim pujian dapat ditandai dengan adanya prasangka negatif, dengan tidak menghargai apa yang dilakukan pembaca, memandang rendah kemampuan pembaca.

Wacana yang berisi tuturan yang menyimpang terhadap maksim penghargaan terdapat pada Bab I dengan judul Mengidentifikasi Isi Teks Laporan Hasil Observasi, dan Menyusun Teks Negosiasi Tulis dalam Bentuk Narasi.

Di antara contoh penyimpangan maksim penghargaan terdapat dalam wacana yang berjudul "Mengidentifikasi Isi Teks Laporan Hasil Observasi” hal 9 pada kalimat "Supaya kamu dapat melakukan kegiatan mendengarkan dengan benar, tutuplah buku ini! (Kode data: 01/3/cc). Kalimat tersebut berupa tuturan deklaratif bermakna imperatif yang mengamanatkan siswa untuk mendengarkan teks laporan observasi yang dibacakan temannya.

Penyimpangan terhadap maksim penghargaan disebabkan kalimat tersebut tidak memberikan penghargaan dan cenderung berprasangka negatif kepada pembaca. Penggunaan kata "benar" menyebabkan kalimat tersebut terkesan memasukkan dugaan atau meragukan kemampuan pembaca dalam mendengarkan teks laporan hasil observasi. Untuk meminimalkan prasangka negatif yang terkandung dalam kalimat (6) di atas, maka penggunaan kata "benar" dapat dihilangkan. Sementara itu, sebagai saran untuk perbaikan kalimat di atas agar kadar suruhannya tidak terkesan memaksa yaitu dengan memanfaatkan maksim permufakatan yang menghendaki parapeserta tutur, hendaknya untuk selalu meningkatkanpersesuaian antara diri sendiri dengan orang lain. 
Oleh karena itu, untuk memaksimalkan kesantunan tuturan di atas, penulis bisa memanfaatkan penanda kesantunan "harap"yang berfungsi sebagai pemerhalus dan pemarkah tuturan bermakna imperatif harapan. Di samping bermakna harapan, tuturan yang disertai dengan penanda kesantunan "harap" juga dapat memiliki makna imbauan. Kalimat "kamu diharapkan dapat mendengarkan teks laporan hasil observasi dan mengetahui isi yang terkandung di dalamnya", terkesan lebih santun bila dibandingkan dengan tuturan "supaya kaтu dapat melakukan kegiatan mendengarkan dengan benar, tutuplah buku ini!". Dengan digunakannya bentuk yang demikian, tuturan di atas terkesan sebagai harapan agar siswa dapat mengetahui isi yang terdapat dalam teks laporan hasil observasi, tanpa adanya dugaan atau meragukan kemampuan siswa.

\section{Tingkat Kesantunan Berbahasa pada Wacana Buku Teks Bahasa Indonesia SMA/MA/ SMK/MAK Kelas X Karangan Suherli dan Kawan-kawan}

Tingkat kesantunan berbahasa dalam wacana buku teks Bahasa Indonesia SMA/MA/SMK/MAK Kelas X Kurikulum 2013 Edisi Revisi 2016 Karangan Suherli dan kawan-kawan berkategori santun. Tingkat kesantunan tersebut didapatkan dengan melihat kecenderungan tingkat kesantunan tuturan dalam wacana buku teks tersebut.

Tuturan yang mematuhi maupun menyimpang terhadap prinsip kesantunan berjumlah 211 tuturan dengan bentuk pematuhan prinsip kesantunan pada wacana berjumlah 157 tuturan, yang terdiri dari 63 maksim kebijaksanaan, 6 maksim kedermawanaan, 18 maksim penghargaan, dan 70 maksim permufakatan. Kemudian data dihitung dengan rumus persentase kesantunan. Hasil keseluruhannya dikonsultasikan dengan tabel pematuhan prinsip-prinsip kesantunan berbahasa. Penghitungan nilai persentase pematuhan dalam penelitian ini sebagai berikut: $K S=$ $\frac{157}{211} \times 100 \%=74,4 \%$. Sedangkan bentuk penyimpangan yang diperoleh 54 tuturan terdiri atas 52 maksim kebijaksanaan dan 2 maksim penghargaan. Data yang diperoleh, kemudian dihitung dengan rumus persentase kesantunan dan hasil keseluruhan dikonsultasikan dengan tabel penyimpangan prinsip kesantunan berbahasa. Penghitungan nilai persentase adalah sebagai berikut: $K s=\frac{54}{211} \times 100 \%=25,6 \%$.

Nilai persentase pematuhan dan penyimpangan di atas kemudian dikonsultasikan dengan tabel persentase kesantunan yang telah ditetapkan. Berdasarkan tabel 
kesantunan tersebut, predikat santun diperoleh apabila jumlah persentase pematuhannya berkisar $61 \%$ - $80 \%$ atau jumlah penyimpangannya berikisar $21 \%$ - 40\%. Dengan demikian, dapat diketahui bahwa Wacana-wacana dalam Buku Teks Bahasa Indonesia SMA/MA/SMK/MAK Kelas X Kurikulum 2013 Edisi Revisi 2016 Karangan Suherli dan kawan-kawan tergolong ke dalam predikat santun. Untuk lebih jelasnya dapat dilihat pada tabel 5 berikut ini.

Tabel 5

Tingkat Kesantunan Berbahasa dalam Wacana pada Buku Teks Bahasa Indonesia

\begin{tabular}{clccc}
\hline \hline No & Kategori & Jumlah Tuturan & Persentase & $\begin{array}{c}\text { Predikat } \\
\text { Kesantunan }\end{array}$ \\
\cline { 1 - 3 } 1 & Pematuhan & 157 Tuturan & $74,4 \%$ & Santun \\
\cline { 1 - 3 } 2 & Penyimpangan & 54 Tuturan & $25,6 \%$ & \\
\cline { 1 - 3 } & JUMLAH & 211 Tuturan & $100 \%$ & \\
\hline
\end{tabular}

\section{SIMPULAN}

Berdasarkan hasil penelitian dan pembahasan tentang Pematuhan dan Penyimpangan terhadap Prinsip Kesantunan Berbahasa dalam Wacana Buku Teks Bahasa Indonesia SMA/MA/SMK/MAK Kelas X Kurikulum 2013 Edisi Revisi 2016 Karangan Suherli dan kawan-kawan, dapat disimpulkan bahwa tuturan yang terindikasi baik mematuhi maupun menyimpang terhadap prinsip kesantunan berbahasa berjumlah 211 tuturan. Bentuk pematuhan prinsip kesantunan pada wacana berjumlah 157 tuturan, yang terdiri dari 63 maksim kebijaksanaan, 6 maksim kedermawanaan, 18 maksim penghargaan, dan 70 maksim permufakatan. Sedangkan, bentuk penyimpangan prinsip kesantunan berbahasa pada wacana berjumlah 54 tuturan, terdiri dari 52 maksim kebijaksanaan dan 2 maksim penghargaan.

Dilihat dari frekuensi pematuhan dan penyimpangan terhadap prinsip-prinsip kesantunan berbahasa, bentuk pematuhan memiliki frekuensi yang lebih besar yaitu 74 dengan kategori santun, sedangkan penyimpangannya memiliki frekuensi yang lebih kecil yaitu 25,6\% dengan kategori santun. Dengan demikian, wacana yang terdapat dalam Buku Teks Bahasa Indonesia SMA/MA/SMK/MAK Kelas X Kurikulum 2013 Edisi Revisi 2016 karangan Suherli dan kawan-kawan dapat dikategorikan santun. 


\section{DAFTAR PUSTAKA}

Chaer, Abdul. (2010). Kesantunan Berbahasa. Jakarta: Rineka Cipta.

Leech, Geoffrey. (2015). Prinsip-Prinsip Pragmatik (Edisi 2015, Oka M.D.D., Terjemahan). Jakarta: Universitas Indonesia Press.

Mulyana. (2005). Kajian Wacana. Yogyakarta: Tiara Wacana.

Muslich, Masnur. (2006). Kesantunan Berbahasa: Sebuah Kajian Sosiolinguistik. (Online). $\quad$ https://id.scribd.com/document/48235235/kesantunan-berbahasa (Diakses tanggal 21 Februari 2017).

Pranowo. (2012). Berbahasa Secara Santun. Yogyakarta: Pustaka Pelajar.

---------. 2014. Teori Belajar Bahasa: untuk Guru Bahasa dan Mahasiswa Jurusan Bahasa. Yogyakarta: Pustaka Pelajar.

Rahardi, Kunjana. (2005). Pragmatik: Kesantunan Imperatif Bahasa Indonesia. Yogyakarta: Erlangga.

Sobur, Alex. (2012). Analisis Teks Media (Suatu Pengantar untuk Analisis Wacana, Analisis Semiotik, dan Analisis Framing). Bandung: Remaja Rosdakarya.

Sosiowati, I Gusti Ayu Gde. (2013). Kesantunan Bahasa Politisi dalam Talk Show di Metro TV. (Disertasi Doktoral, Universitas Udayana, 2013). (Online) http://www.pps.unud.ac.id/disertasi/detail-66-kesantunan-bahasa-politisi--dalamtalk-show-di-metro-tv.html (Diakses tanggal 18 April 2017).

Sukmadinata, Nana Syaodih. (2010). Metode Penelitian Pendidikan. Bandung: Remaja Rosdakarya.

Tarigan, Henry Guntur dan Djago Tarigan. (2009). Telaah Buku Teks Bahasa Indonesia. Bandung: Angkasa.

Zamzani, (2011). Pengembangan Alat Ukur Kesantunan Bahasa Indonesia dalam Interaksi Sosial Bersemuka. Jurnal Litera UNY, Vol. 10, No. 1, April 2011, 3550. (http://journal.uny.ac.id/index.php/litera/article/view/1171) (Diakses tanggal 10 Februari 2017). 